\title{
Ozone (03) and SARS-CoV-2: Physiological Bases and Their Therapeutic Possibilities According to COVID-19 Evolutionary Stage
}

\author{
Marcos Edgar Fernández-Cuadros ${ }^{1}$ (D) - María Jesús Albaladejo-Florín ${ }^{1} \cdot$ Daiana Peña-Lora $^{2} \cdot$ Sandra Álava-Rabasa $^{1}$. \\ Olga Susana Pérez-Moro ${ }^{1}$
}

Accepted: 19 May 2020 / Published online: 7 July 2020

(C) Springer Nature Switzerland AG 2020

\begin{abstract}
To date, there is no definitive treatment for the new SARS-CoV-2 pandemic. Three evolutionary stages in SARS-CoV-2 infection are recognized (early infection, pulmonary phase, and systemic hyper inflammation), with characteristic clinical signs and symptoms. There are 80 international experimental trials underway seeking effective treatment for the COVID-19 pandemic. Of these, there are only three that consider ozone therapy (major auto hemotherapy) as an alternative option. There is no study that evaluates rectal ozone insufflation, despite being a safe, cheap, risk-free technique. That technique is a systemic route of ozone administration (95-96\%) and that could be extrapolated to the use of SARS-CoV-2, given the excellent results observed in the management of Ebola. Ozone has four proven biological properties that could allow its use as an alternative therapy in the different phases of SARS-CoV-2 infection. Ozone could inactivate the virus by direct (O3) or indirect oxidation (ROS and LOPs) and could stimulate the cellular and humoral immune systems, being useful in the early COVID-19 infection phase (stages 1 and 2a). Ozone improves gas exchange, reduces inflammation, and modulates the antioxidant system, so it would be useful in the hyper inflammation or "cytokine storm" phase, and in the hypoxemia and/or multi-organ failure phase (stage $2 \mathrm{~b}$ and stage 3). Given the current pandemic, it is urgent to carry out an experimental study that confirms or rules out the biological properties of ozone and thus allows it to be an alternative or compassionate therapy for the effective management of SARS-Cov-2 infection. The Ethical Committee at our Hospital has authorized the use of this technique for compassionate management of SARS-CoV-2 infection, considering the four biological Ozone properties exposed previously.
\end{abstract}

Keywords Coronavirus $\cdot$ Pandemic $\cdot$ Ozone $\cdot$ SARS-CoV-2 $\cdot$ COVID-19

\section{Introduction}

Coronaviruses (CoV) are large RNA viruses, spherical in shape, from which protrude corona-shaped spicules (S-protein, basically made up of cysteine and tryptophan). They can cause pathology in animals (mammals and birds) and

This article is part of the Topical Collection on Covid-19

Marcos Edgar Fernández-Cuadros marcosefc@hotmail.com

1 Calle del Maestro Vives 2 y 3, Servicio de Medicina Física y Rehabilitación, Hospital Universitario Santa Cristina, CP28009 Madrid, Spain

2 Unidad de Geriatría, Hospital Universitario Santa Cristina, Madrid, Spain humans. Human coronaviruses were first isolated in 1960. Seven types of human $\mathrm{CoV}$ are known, of which four cause the common cold (HCoV-229E, HCoV-OC43, HCoV-NL63, and $\mathrm{HCoV}-\mathrm{HKU} 1)$. In this twenty-first century, three other new $\mathrm{CoV}$ have appeared whose pathogenicity is much more serious and causes severe acute respiratory syndrome (SARS), which are SARS-CoV (China, 2002), MERS-CoV (Middle East, 2012), and SARS-CoV-2 [1, 2].

An outbreak of cases of pneumonia caused by a new coronavirus, SARS-CoV-2 or COVID-19, has been reported in December 2019 in Wuhan, Hubei province (China) [3]. From China, it has spread in 3 months to practically all over the world, impacting on the economy and health of the affected countries. This pandemic has had an impact on health systems, which to date (April 5, 2020), there are 897,013 confirmed cases in 196 countries and more than 65,712 deaths [4]. 
The current pandemic confirms that SARS-CoV-2 is a highly infectious virus with a high transmission capacity. It is transmitted through Flügge droplets from the respiratory secretions of an infected person (by exhaling, coughing, or sneezing) and is capable of transmission over distances of up to $2 \mathrm{~m}$. When Flügge droplets fall, they deposit on surfaces, where they can infect other people if they touch those objects or surfaces with their hands and then bring them to their eyes, nose, or mouth [5].

The high infectivity rate and the high incubation time (between 1 and 14 days) of this virus provide great presymptomatic transmissibility. Furthermore, after healing, transmission is also possible ( 15 days post-cure). Fecal-oral transmission is plausible, causing digestive symptoms (diarrhea). No cases of perinatal or breast milk transmission have been reported [6].

To date, there is no effective antiviral treatment against SARS-CoV-2. Antiviral drugs and systemic corticosteroids used in other viral infections (SARS-CoV and MERS-CoV) have not demonstrated validity for SARS-CoV-2 [7]. Some authors highlight the use of corticosteroids at the start of the hyper inflammatory response and not in early stages, where their early use could favor viral replication [8]. Remdesivir (antiviral RNA) has been successfully used to treat the first case of SARS-CoV-2 in the United States [9]. Remdesivir is the most promising antiviral currently investigated, although neither its efficacy nor safety is established [9]. Lopinavir/ Ritonavir significantly decreased viral load in one case of SARS-CoV-2, although the efficacy of this combination is not definitively established [10]. Several studies have found that hydroxychloroquine may inhibit some steps in the replication of several viruses, including $\mathrm{CoV}$ [11]. Hydroxychloroquine also has an immunomodulatory effect, suppressing production and release of TNF- $\alpha$ and IL-6 [12]. Currently, the efficacy, dose, and safety of hydroxychloroquine for the treatment and prevention of SARS-CoV-2 are not established, and more data is needed on whether the in vitro activity corresponds to clinical efficacy [12]. A recent publication states that the combined use of hydroxychloroquine and azithromycin is more effective in eliminating the virus [13].

Various quasi-experimental protocols are being evaluated at the hospital level to modulate the excessive immune response, to suppress different proinflammatory cytokines, and thus to avoid the damage produced by the cytokine storm, because this phenomenon is responsible for the fatal outcome in infection by SARS-Cov-2 [14].

Several studies (Cuba, Italy, Germany, Russia, and Spain) and years of experience have shown that ozone $(\mathrm{O} 3)$ is capable of modulating inflammation and pain, in addition to having demonstrated a bactericidal, fungicidal, virucidal, and antiparasitic effect $[15,16]$. These antimicrobial properties have made ozone recognized as such an effective disinfectant that it is used in many water purification plants worldwide [15]. In this context, we reasonably believe that ozone has a place in the management of the present SARS-CoV-2 pandemic, so we will carry out a review on the subject and its therapeutic possibilities.

Currently, about 80 clinical trials are being carried out that seek to define the best therapy for the management of SARSCov-2 infections, of which only 3 are dedicated to the study of ozone on this disease and its potential therapeutic use [4].

The objective of this review is to analyze the physiological bases and therapeutic possibilities of ozone on SARS-Cov2 (COVID-19) infection according to evolutionary stage and perhaps propose its use as complementary therapy in the compassionate treatment of COVID-19, using as a systemically administered rectal insufflation route, because it is the simplest, safest, and cheapest technique.

\section{Physiopathology of SARS-Cov-2}

SARS-CoV-2 infection produces an immune response in two phases [17]; a first in which viral pathogenicity predominates, and a second, in which the pathology is mainly due to the excessive host immune response [17]. The transition from one phase to another is progressive, both clinically and analytically [14].

During incubation and in the non-severe phase of the disease, a specific adaptive immune response is required to try to eliminate the virus and limit progression to more advanced stages of infection. The second phase begins when the protective immune response is altered. An immune system dysfunction generates a decrease in CD3 + and CD4 + T lymphocytes accompanied by an increase in neutrophils and an increase in the neutrophil/lymphocyte index, especially in the most severe cases, being a predictive sign of torpid evolution [18].

Immune system dysfunction originates disproportionate and negative immune responses for the different affected tissues. Recruitment of signaling complexes develops a molecular cascade that activates nuclear transcription factor-K $\beta$ $(\mathrm{NF}-\mathrm{K} \beta$ ) and interferon regulatory factor 3 (IRF3) and the production of type I interferons (IFN- $\alpha / \beta)$ and a series of pro-inflammatory cytokines (mainly IL- $1 \beta$, IL-6, macrophage colony-stimulating factor [MCSF], IP-10, MCP-1, hepatocyte growth factor [HGF], interferon- $\gamma[$ IFN- $\gamma]$, and tumor necrosis factor- $\alpha[$ TNF- $\alpha])$. The cytokine profile associated with COVID-19 severity resembles that seen in Secondary Haemophagocytic Lymphohistiocytosis (SHLH) [19]. SHLH is a poorly understood hyper inflammatory syndrome characterized by fulminant hypercytokinemia and fatal multiorgan failure, representing $3.7-4.3 \%$ of cases of viral sepsis in adults. SHLH is associated with sustained fever, cytopenia, elevated ferritin, and lung involvement in $50 \%$ of patients [20]. In a multicenter retrospective study of 150 cases of COVID-19 in Wuhan, the mortality was attributed to viral 
hyper inflammation, and increased ferritin and IL-6 were considered markers of serious disease [21]. Other predictors of severe SARS-CoV-2 disease were elevated D-Dimer, lymphopenia, and increased ultra-sensitive troponin-I [22].

The current treatment for COVID-19 is maintenance, and respiratory failure due to acute respiratory distress syndrome (ARDS) is the main cause of mortality. A subgroup of patients with severe COVID-19 could develop "cytokine storm" syndrome [23]. To reduce mortality, there is a need to identify and treat hyper inflammation using all existing therapies with acceptable safety profiles, as soon as possible [24].

\section{Clinical Presentation of SARS-CoV-2}

SARS-Cov-2 infection does not progress similarly in everyone who comes in contact with the virus. A small percentage of exposed people do not become infected or develop clinical symptoms (30\%). The interest in the clinical classification lies in being able to propose the most appropriate therapeutic approach for each patient according to the phase in which they are found [14].

Siddiqi and Mehra have proposed a classification of the disease in three states or phases [25].

- State I (mild or early infection), ranging from inoculation to the early establishment of the disease, characterized by nonspecific symptoms such as malaise, fever, dry cough, headache, anosmia, or ageusia. At the analytical level, the hemogram can reveal lymphopenia and neutrophilia without other significant abnormalities (Table 1) [25].

- State II (moderate infection, with respiratory involvement without hypoxemia [IIa] or with hypoxemia [IIb]). Establishment of respiratory disease with worsening of symptoms and the appearance of radiological signs of viral pneumonia (infiltrates or ground-glass opacities that are characteristically bilateral [radiography and tomography observed in Table 1]) and analytical features (exacerbation of lymphocytopenia, moderate elevation of $\mathrm{D}$ dimer and transaminases), as well as the beginning of elevation of systemic markers of inflammation but not exaggerated (normal or low procalcitonin). At this stage, most patients with COVID-19 would need to be hospitalized for observation and treatment (15\%). A relevant clinical aspect in this period is the appearance of hypoxemia as a marker of the progress of the infection and the need for mechanical ventilation as a result of the pulmonary inflammatory hyper response, which, if not interrupted, will lead to the next state (Table 1) [25].

- State III (severe or of systemic hyper inflammation). Clinically, in this phase, multiorgan involvement is observed in many patients with a progressive evolution towards worsening and hemodynamic instability and sepsis.
This period is characterized by a significant elevation of systemic inflammation markers (IL-2, IL-6, and IL-7, granulocyte colony stimulating factor, macrophage inflammatory protein $1-\alpha$, TNF- $\alpha$, C-reactive protein [PCR], ferritin, and D-dimer). Ferritin is the key indicator of macrophage activation. D-dimer rises in a similar way to antiphospholipid syndrome together with low platelets and coagulation disorders (Table 1) [25].

\section{Ozone and Medicinal Properties}

Ozone is a strong oxidizing agent (the third if compared to fluorine and persulfate) and a molecule with a high reactivity [26].

Ozone (O3) is the unstable (allotropic) form of oxygen [27-29]. Various infectious, autoimmune, and degenerative diseases are treated by $\mathrm{O} 3$ [30]. Ozone is an immunomodulatory, anti-inflammatory, analgesic, and trophic agent [29].

Ozone is not storable because it decomposes spontaneously. To date, $\mathrm{O} 3$ concentration is halved at $30{ }^{\circ} \mathrm{C}$ within $25 \mathrm{~min}$, at $20{ }^{\circ} \mathrm{C}$ in $40 \mathrm{~min}$, and at $-50{ }^{\circ} \mathrm{C}$ in 3 months [26]. Ozone decomposes rapidly, dividing into $\mathrm{O} 2$ and $\mathrm{O}^{-}$(monatomic $\mathrm{O}$ ). Ozone disintegration releases heat $(24.27 \mathrm{kcal})$ and produces vasodilator effect. This molecule is highly reactive, and therefore, antifungal, antiparasitic, and antiviral properties are attributed [31].

Ozone has a dose/effect relationship and therefore is not considered a homeopathic medicine. On the contrary [26, 32], ozone generators release concentrations from 1 to 70 $100 \mu \mathrm{g} / \mathrm{ml}$, although the therapeutic window is between 10 and $80 \mu \mathrm{g} / \mathrm{ml}$ [31]. The $\mathrm{O} 3$ total dose is equivalent to the volume of gas ( $\mathrm{ml})$ multiplied by $\mathrm{O} 3$ concentration $(\mu \mathrm{g} / \mathrm{ml})$.

Ozone, when dissolved in plasma, reacts with a series of biomolecules and then disappears. There are two compounds (reactive species of oxygen or ROS and lipid oxidation products or LOPs) that represent the "ozone messengers". They are responsible for the biological and therapeutic effects. ROS are produced immediately in the initial phase (mainly hydrogen peroxide or $\mathrm{H}_{2} \mathrm{O}_{2}$ ) and are responsible for the early biological effects on the blood (erythrocytes, leukocytes, platelets). In contrast, LOPs, which are produced simultaneously, have a longer half-life, reach the vascular system, and interact with various organs, where they trigger late effects. Some of these target organs are the liver (in chronic hepatitis), the vascular system (in vasculopathies), while other organs are likely involved in the restoration of normal homeostasis (central nervous system, gastrointestinal tract, lymphoid tissue associated with mucosa) [26, 30, 32].

The biological effects of ozone in plasma are due to the formation of ROS and LOPs (ozone messengers). ROS improve $\mathrm{O}_{2}$ delivery in erythrocytes. ROS also activate the immune system 
Table 1 Severity of SARS-Cov-2 Infection by stages, signs, symptoms [25], potential therapies and ozone therapy proposal according to properties/ evolution of COVID-19 disease

\begin{tabular}{|c|c|c|c|c|}
\hline STATE & $\begin{array}{c}\text { STATE } 1 \\
\text { (Early infection) }\end{array}$ & $\begin{array}{r}\text { STAT } \\
\text { (2a [without hypoxia] } \\
\text { (Pulmona }\end{array}$ & $\begin{array}{l}2 \\
2 b \text { [with hypoxia]) } \\
\text { ohase) }\end{array}$ & $\begin{array}{c}\text { STATE } 3 \\
\text { (Systemic hiper } \\
\text { inflammation) }\end{array}$ \\
\hline \multirow{2}{*}{ Severity } & \multicolumn{3}{|l|}{ Phase of viral response } & \\
\hline & & \multicolumn{3}{|c|}{ Phase of host hiperresponse (cytokine storm) } \\
\hline Symptoms & $\begin{array}{l}\text { Mild general symptoms } \\
\text { (fever, dry cough, diarrhea, } \\
\text { headache) }\end{array}$ & Disnea, Hypoxia $\left(\mathrm{PaO}_{2} / \mathrm{FiO}_{2}\right.$ & $300 \mathrm{mmHg})$ & $\begin{array}{l}\text { SARS, MOFS, } \\
\text { Shock, Cardiac } \\
\text { Failure }\end{array}$ \\
\hline Signs & $\begin{array}{l}\text { Linfopenia, increase in } \\
\text { prothrombine time, mild D- } \\
\text { dimer and LDH increase }\end{array}$ & $\begin{array}{l}\text { Abnormal radiologic thorax } \\
\text { Elevated Transaminases } \\
\text { Normal or low Procalcitonin }\end{array}$ & nage & $\begin{array}{l}\text { Increased } \\
\text { markers of } \\
\text { Inflammation } \\
\text { (LDH, CRP, IL-6, } \\
\text { Ferritin), } \\
\text { elevation of } \\
\text { troponin and NT- } \\
\text { proBNP }\end{array}$ \\
\hline \multirow{3}{*}{$\begin{array}{l}\text { Potential } \\
\text { Therapies }\end{array}$} & \multicolumn{4}{|c|}{ Remdesivir, chloroquine, hidroxicloroquine, convalescent serum transfussion } \\
\hline & \multicolumn{2}{|l|}{ Favors immune response } & \multicolumn{2}{|c|}{$\begin{array}{l}\text { Inmunosupression: Corticosteroids, human } \\
\text { immunoglobulin, inhibitors of IL-1, IL-6, IL- } \\
\text { 2, inhibitors of JAK. }\end{array}$} \\
\hline & $\begin{array}{l}\text { Ozone }(\mathrm{O} 3) \text { as viral inhibitor } \\
\text { [virucidal]. }\end{array}$ & $\begin{array}{l}\text { Ozono }(\mathrm{O} 3) \text { as cellular and } \\
\text { humoral stimulator } \\
\text { [stimulating NFAT-cell and } \\
\text { AP-1 pathway]. }\end{array}$ & $\begin{array}{l}\text { Ozone (O3) } \\
\text { (decreases IL1, IL-- } \\
\text { 10). O3 blocks } \\
\text { stimulates Nrf2 pa } \\
\text { storm]. } \\
\text { Ozone might favor } \\
\text { permeability (h } \\
\text { multiorgan failure]. }\end{array}$ & $\begin{array}{l}\text { mmunomodulator } \\
\alpha \text {, stimulates IL- } \\
3 \text { pathway and } \\
\text { [Useful in cytokine } \\
\text { very and red blood } \\
\text { ia). [Useful in }\end{array}$ \\
\hline
\end{tabular}

$S R A S$ severe acute respiratory syndrome, $M O F S$ multiorganic failure syndrome, $C R P$ C-reactive protein, $L D H$ lactato deshidrogenase, $N T$-proBNP Nterminal pro-brain natriuretic peptide, $I l$ interleukina, $N F A T$ cell nuclear factor activated T cell, $J A K$ Janus kinase, $N F-K \beta$ nuclear factor-K $\beta, A P-1$ activated protein-1, $N r f 2$ nuclear eritroid factor 2

by stimulation of leukocytes. In platelets, ozone favors the release of cytokines (local hormones) and growth factors. In the endothelium, LOPs increase the release of NO (nitric oxide). In bone marrow, LOPs favor the release of stem cells and generation of gifted erythrocytes. Finally, LOPs act on other organs, activating the positive regulation of oxidative shock proteins (OSP) and antioxidant enzymes (superoxide dismutase, catalase, and glutathione peroxidase) $[26,32]$.

Ozone modulates inflammation and oxidative stress, stabilizing the pro-oxidant and antioxidant balance [31]. In summary, ozone increases the rheological properties of the blood, improves the delivery of $\mathrm{O}_{2}$, the endothelial production of $\mathrm{NO}$, and modulation of immunity via cytokine induction. In this sense, ozone $(\mathrm{O} 3)$ is the "ideal" cytokine inducer (Table 2) [26, 32].

\section{Potential Properties of Ozone on SARS-COV-2}

Ozone has many properties that could cope with COVID-19 infection, and its different properties can act on the different evolutionary stages of the infection. Babior et al. have shown that our immune system is capable of producing ozone to develop bactericidal activity [33]. Bocci has shown that ozone is also active against viruses, fungi, yeasts, and protozoa $[26,32]$. 
Table 2 Effect of ozone on target organs and functional modifications [26]

\begin{tabular}{llll}
\hline Sustrate & Messenger & Target & Functional modifications \\
\hline Ozone in serum & ROS & Erythrocytes & Favors delivery of $\mathrm{O}_{2}$ (by 2,3DPG) \\
& Leucocytes & Activates immunity \\
& Platelets & Release of cytokines and growth factors \\
& Endothelium & Release of NO and super gifted erythrocytes \\
& Bone marrow & Release of stem cells \\
& Other organs & Regulation of oxidative shock proteins \\
& & and antioxidant enzymes \\
\end{tabular}

$R O S$ reactive oxygen species, $L O P S$ lipid oxidative products, $N O$ nitric oxide, 2,3 DPG 2,3 diphosfoglicerate
Four properties are proposed for which ozone would be useful in the management of SARS-COV-2.

Property 1 Rowen states that ozone is capable of directly inactivating many viruses (Norwalk virus, Hepatitis A virus, poliovirus and MS3 colofagus) [34]. The explanation for the "virucidal" effect is that ozone is capable of oxidizing the glycoprotein of its membrane, transforming it from the reduced form (R-S-H) to the oxidized form (R-S-S-R). The virus normally requires the reduced form to enter cells and infect them [34]. Mirazmi has observed that CMV (cytomegalovirus) loses infectivity if its "thiol" or sulfhydryl (R-S-H) group is oxidized (R-S-S-R), as Rowen observed. Coronaviruses, as well as Ebola virus, have regions rich in cysteine and tryptophan in their membrane S-protein (spike-S) [34, 35]. Rowen and Eren postulate that ozone would directly oxidize the "thiol" (R-S-H) groups of cysteine and tryptophan to the R-S-S-H form, inactivating them, directly blocking their cellular fusion. If the ozone does not arrive directly, its messengers, such as ROS or LOPs $\left(\mathrm{H}_{2} \mathrm{O}_{2}\right.$, superoxide, nitric oxide, etc.), still maintain their oxidizing power to inactivate viruses (Fig. 1) [34-38]. If ozone by the peroxidation process damages the capsid, the reproductive cycle of the virus is altered, therein would be the therapeutic effect of ozone in the initial phase (state 1) of early infection (Table 1, Fig. 2).

Property 2 Ozone, via second messengers $\left(\mathrm{H}_{2} \mathrm{O}_{2}\right)$, is capable of stimulating cellular and humoral immunity, through the NFAT (nuclear factor activated T cells) signaling pathway and the AP-1 (activated protein-1) pathway [39]. These pathways are crucial transcription factors since they would induce the expression of genes to release inflammatory cytokines (IL-2, IL-6, IL-8, TNF- $\alpha$, and IFN- $\gamma$ ) that will produce the inflammation that will recruit the neutrophils, lymphocytes, and macrophages, in order to carry out phagocytosis to limit infection at that level, killing local pathogens $[26,39]$. This property of ozone would allow acting in the viral response phase (state 1 and state 2) of the viral infection (Table 1, Fig. 2).
Fig. 1 The coronavirus owes its name to the protein around it that has a crown shape (S-spike protein) and that is made up of cysteine and tryptophan. Ozone (O3) or its mediators (ozonides [ROS, LOPs]) are capable of oxidizing these residues, preventing their binding to the ACE2 (angiotensin converting enzyme 2 ) receptor of type 2 pneumocyte

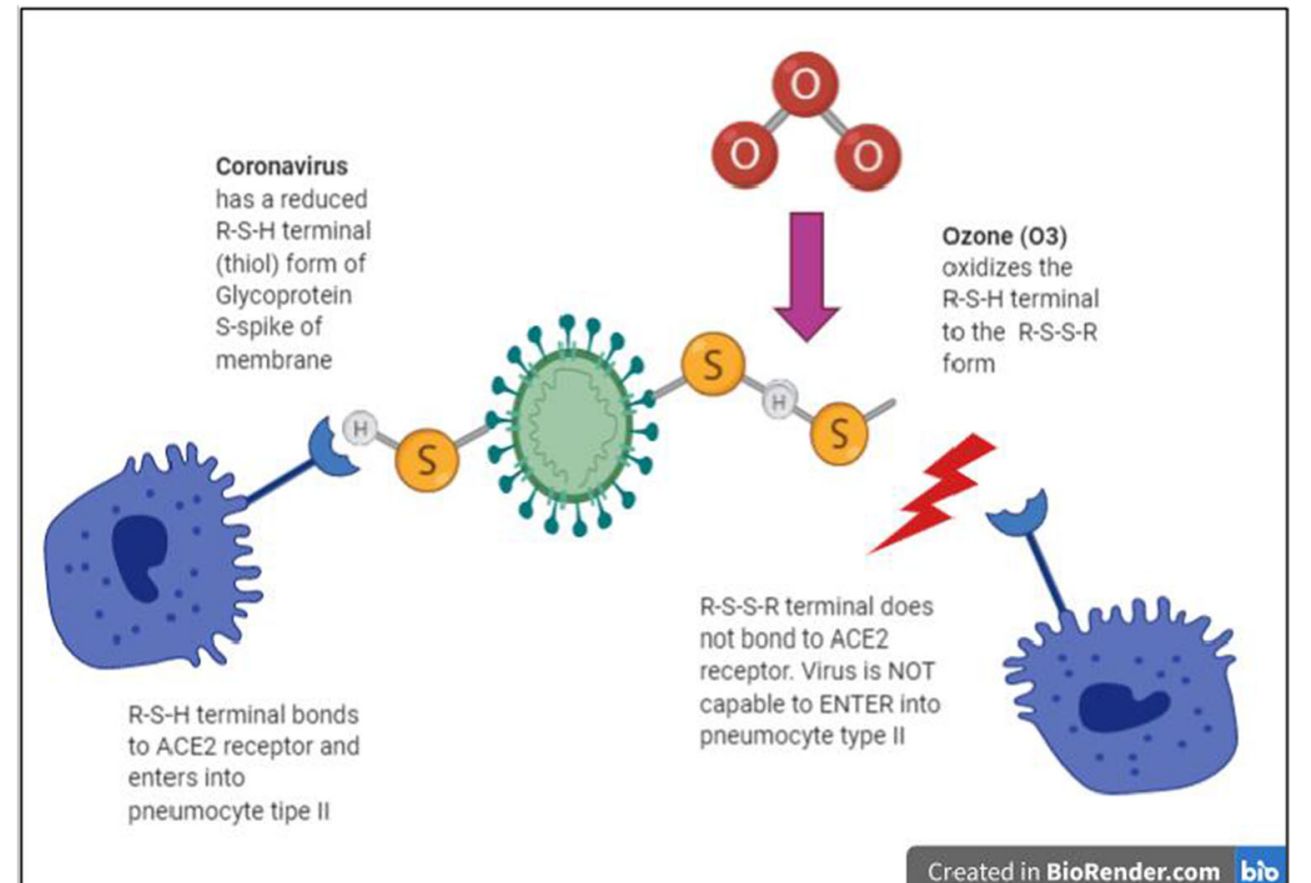

Created in BioRender.com bio 
Fig. 2 Effects/properties of ozone (O3): (1) oxidation at the level of protein $\mathrm{S}$ (spikes) rich in cysteine and tryptophan. (2) Stimulation of cellular and humoral immunity (call for neutrophils, macrophages, etc.). (3) Inhibition of IL1 , IL-6, TNF- $\alpha$ (via NRf2, Via NF-K $\beta$ ). (4) Improvement of hypoxemia (by 2,3 DPG release and $\mathrm{O} 2$ dissociation) and improvement of rheological properties of red blood cells)

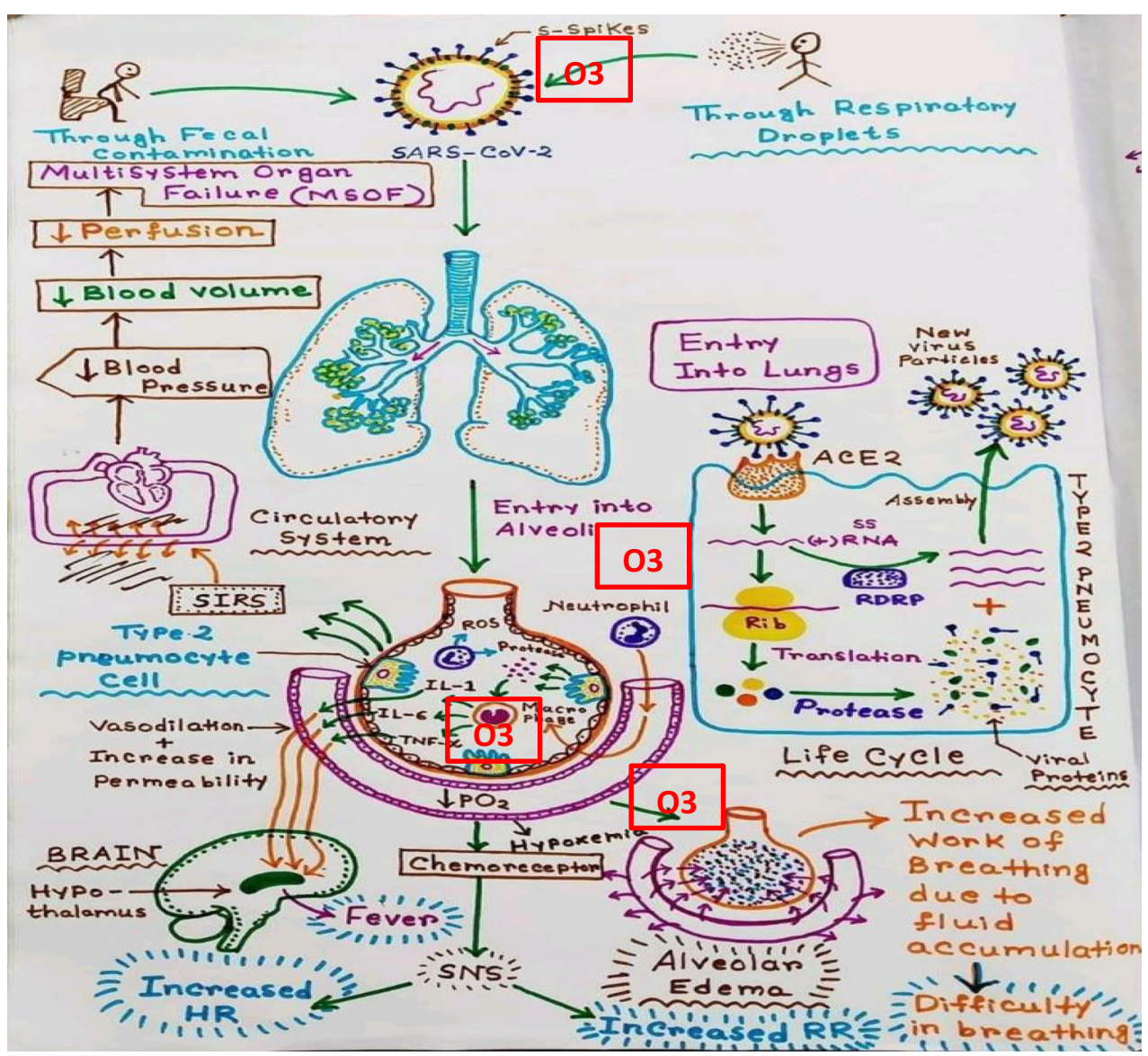

Property 3 Ozone at therapeutic doses modulates erythroid nuclear factor type 2 (Nrf2) and NF-K $\beta$ and induces the rebalancing of the antioxidant environment [40-44]. Nrf2 is the key transcriptionist that controls various aspects related to cellular homeostasis in response to toxic or oxidizing agents. In particular, the effects of Nrf2 mediate basal or induced transcription of phase II antioxidant enzymes (it produces the enzymes catalase, glutathione peroxidase, and superoxide dismutase), which are the enzymes responsible for the elimination of ROS. During acute inflammatory processes, to increase the magnitude of the response, NF-kB promotes increased activity of mitochondrial NADPH oxidase, the main source of endogenous superoxide anion radical. It is now clear that there are strong links between the coordinated activity of gene activation by both transcription factors (NF-kB and $\mathrm{Nrf}$ ) to solve inflammatory processes at the cellular and tissue level. An imbalance between the NF-kB and Nrf2 routes is associated with a large number of diseases, as is the case of COVID-19 complications [43, 44]. Fernández-Cuadros has stated that ozone is capable of blocking the NF-K $\beta$ pathway, decreasing proinflammatory cytokines IL-1, IL-6, TNF- $\alpha$, and stimulating anti-inflammatory cytokines IL-4 and IL-10 [45, 46]. Furthermore, in a recent study, Fernández-Cuadros has observed that ozone is capable of modulating inflammation, decreasing inflammation markers such as CRP (C-reactive protein) and ESR (erythrocyte sedimentation rate) [16]. Due to these characteristics, we believe that ozone could modulate inflammation and have a therapeutic role in the hyper inflammation phase, acting on the "cytokine storm" (Table 1, Fig. 2).

Property 4 Ozone could improve the circulation and perfusion of the lung and of all the organs in a state of hypoxia. Ozone improves the metabolism of oxygen $[15,26]$. Ozonized erythrocytes show improved glycolysis with increased levels of ATP and 2,3-DPG (diphosphoglycerate), which can shift the $\mathrm{HbO}_{2}$ dissociation curve to the right, increase arterial $\mathrm{PO}_{2}$, and decrease venous $\mathrm{PO}_{2}$ (Bhor effect), improving oxygen supply to ischemic tissues $[15,26]$. Continuous applications of ozone stimulate the bone marrow and induce it to generate new "gifted erythrocytes" with an increase in the content of 2,3-DPG, as well as an elevation of glucose 6-phosphate dehydrogenase (G6PD); this may allow a profound modification of functional activities leading tissues and organs from a hypoxic to a normoxic state $[15,26]$. Patients with SARS-CoV-2 are likely to have mild non-specific hepatitis, pulmonary fibrosis, and renal failure [47]. Ozone therapy stabilizes liver metabolism and plasma fibrinogen and prothrombin levels tend to normalize in infected patients, suggesting an improvement in the synthesis of liver proteins [47]. There is enough research showing 
the protective effect of ozone to prevent oxidative damage to the heart, liver, lung, and kidney tissues [47]. For these reasons, we believe that ozone would be useful in the phase of hyper inflammation and multi-organ failure, restoring hypoxemia (Table 1, Fig. 2).

\section{Method of Administration}

Ozone can be administered by different routes, by the systemic (major autohemotherapy, saturated saline solution, rectal and vaginal insufflation) or non-systemic technique (minor autohemotherapy and bag ozone therapy) $[26,31]$. There are currently three clinical trials that are being carried out in China and seek to assess the effectiveness of major autohemotherapy on SARS-CoV-2 [4]. There is no experimental study that is assessing the administration of systemic ozone by rectal insufflation technique. In this review, we propose that a systemic route, easy to carry out, for the administration of ozone, is the rectal route. The Ethical Committee at our Hospital has authorized the use of this technique for compassionate management of SARS-CoV-2 infection, considering the four biological ozone properties exposed previously.

The rectal insufflation method is a technique of systemic application of ozone that delivers 95-96\% of ozone compared to the major autohemotherapy route (100\% delivery of ozone), but without the risks or technical difficulties involved in venous extraction, venous oxygenation, and reinfusion. The proposed technique, according to the International Declaration of Ozone Therapy in Madrid, is to administer a volume of between 100 and $300 \mathrm{cc}$ of rectal ozone at a concentration of $25 \mu \mathrm{g} / \mathrm{ml}$, to gradually increase every 3 days, until reaching a maximum concentration of $35-39 \mu \mathrm{g} / \mathrm{ml}$, in an expected time of 10 daily sessions [48].

Rowen, with the same administration technique (rectal ozone), applied to five patients with Ebola (disease that presents a mortality of 60\%), has reported a success rate of $100 \%$. Rowen noted improvement from the first insufflation, although he completed up to five treatment sessions. With this encouraging report, we believe that this experience can be extended to the management of SARS-Cov-2 [49].

\section{Conclusions}

To date, there is no definitive treatment for the new SARSCoV-2 pandemic. There are 80 international experimental trials underway seeking effective treatment for the COVID-19 pandemic. Of these, there are only three that they consider as alternatives to ozone therapy (major autohemotherapy). There is no study evaluating rectal ozone insufflation, despite being a safe, inexpensive, risk-free technique that is a systemic route of administration (ozone 95-96\%) and that could be extrapolated to the use of SARS-CoV-2, given the excellent results observed in the management of Ebola.

Ozone has four proven biological properties that could allow its use as an alternative therapy in the different phases of SARS-CoV-2 infection. Ozone could inactivate the virus by direct $(\mathrm{O} 3)$ or indirect oxidation (ROS and LOPs) and could stimulate the cellular and humoral immune systems, being useful in the early COVID-19 infection phase (states 1 and $2 a$ ). Ozone improves gas exchange, reduces inflammation, and modulates the antioxidant system, so it would be useful in the hyper inflammation or cytokine storm phase, and in the hypoxemia and/or multi-organ failure phase (state $2 b$ and state 3 ).

Given the current pandemic, it is urgent to carry out an experimental study that confirms or rules out the biological properties of ozone and thus allows it to be an alternative or compassionate therapy for the effective management of SARS-Cov-2 infection.

Acknowledgments Saturnino Díaz Trujillo (librarian at the Hospital Universitario Santa Cristina) is acknowledged for the bibliographic search for the realization of this study.

Funding Information Authors declare no financial funding/support for the elaboration of this manuscript.

\section{Compliance with Ethical Standards}

All authors declare responsibility for the content of the manuscript sent having participated in the design and drafting of the REVIEW/STUDY PROTOCOL.

The manuscript is original work of authors. All data, tables, figures, etc. used in the manuscript are prepared originally by authors.

The manuscript has not been and will not be published elsewhere or submitted elsewhere for publication.

The authors note that there is no commercial relationship giving rise to a conflict of interest in conducting this study.

The review/study protocol complies with current ethical considerations. For the treatment used in this research article (1), informed consent was obtained from the patient included in the study and [2] the study protocol conforms to the ethical guidelines of the 1975 Declaration of Helsinki as reflected in a priori approval by the institution's human research committee.

Finally, we undersigned declare that all authors meet the requirements of authorship and give authorization for the transfer of all copyright on the publication to SN Comprehensive Clinical Medicine.

Conflict of Interest The authors declare that they have no conflict of interest.

Ethical Approval The Study Protocol has been approved by the Ethical Committee of the Hospital (15th April 2020).

Informed Consent Not applicable.

\section{References}

1. Yin Y, Wunderink RG. MERS, SARS and other coronaviruses as causes of pneumonia. Respirology. 2018;23(2):130-7. https://doi. org/10.1111/resp.13196. 
2. Gorbalenya, A. E., Baker, S. C., Baric, R. S., de Groot, R. J., Drosten, C., Gulyaeva, A. A., . \& Neuman, B. W. (2020). Severe acute respiratory syndrome-related coronavirus: the species and its viruses: a statement of the Coronavirus Study Group. bioRxiv ; published online Feb 11. 10(2020.02), 07-937862.

3. Chen, N., Zhou, M., Dong, X., Qu, J., Gong, F., Han, Y., \& \& Yu, T. (2020). Epidemiological and clinical characteristics of 99 cases of 2019 novel coronavirus pneumonia in Wuhan, China: a descriptive study. Lancet, 395(10223), 507-513.

4. WHO Coronavirus disease (COVID-2019) situation reports. 2020.

5. Hung LS. The SARS epidemic in Hong Kong: what lessons have we learned? J R Soc Med. 2003;96(8):374-8.

6. Chen N, Zhou M, et al. Epidemiological and clinical characteristics of 99 cases of 2019 novel coronavirus pneumonia in Wuhan, China: a descriptive study. Lancet, 2020. 395:507-13. https://doi. org/10.1016/S0140-6736(20)30211-7.

7. Li H, Zhou Y, Zhang M, Zhao Q, Liu J. Updated approaches against SARS-CoV-2. Antimicrob Agents Chemother. 2020.

8. Russell CD, Millar JE, Baillie JK. Clinical evidence does not support corticosteroid treatment for 2019-nCoV lung injury. Lancet. 2020;395(10223):473-5.

9. Wang, M., Cao, R., Zhang, L., Yang, X., Liu, J., Xu, M., . \& Xiao, G. (2020). Remdesivir and chloroquine effectively inhibit the recently emerged novel coronavirus (2019-nCoV) in vitro. Cell Res, 30(3), 269-271.

10. Lim, J., Jeon, S., Shin, H. Y., Kim, M. J., Seong, Y. M., Lee, W. J., . \& Park, S. J. (2020). Case of the index patient who caused tertiary transmission of COVID-19 infection in Korea: the application of lopinavir/ritonavir for the treatment of COVID-19 infected pneumonia monitored by quantitative RT-PCR. J Korean Med Sci, $35(6)$.

11. Vincent, M. J., Bergeron, E., Benjannet, S., Erickson, B. R., Rollin, P. E., Ksiazek, T. G., . \& Nichol, S. T. (2005). Chloroquine is a potent inhibitor of SARS coronavirus infection and spread. Virol J, 2(1), 69 .

12. Devaux CA, Rolain JM, Colson P, Raoult D. New insights on the antiviral effects of chloroquine against coronavirus: what to expect for COVID-19? Int J Antimicrob Agents. 2020:105938.

13. Gautret, P., Lagier, J. C., Parola, P., Meddeb, L., Mailhe, M., Doudier, B., . \& Honoré, S. (2020). Hydroxychloroquine and azithromycin as a treatment of COVID-19: results of an openlabel non-randomized clinical trial. Int J Antimicrob Agents, 105949.

14. Carrillo B, Martínez E. COVID-19 y Acupuntura: ¿existe una nueva línea de investigación terapéutica? Revista Digital de Acupuntura. Número Extraordinario Marzo. 2020;3(1):1-21.

15. Fernandez-Cuadros ME, Perez-Moro OS, Albaladejo-Florin MJ. Ozone fundamentals and effectiveness in knee pain: chondromalacia and knee osteoarthritis. Saarbrücken: Lambert Academic Publishing; 2016.

16. Fernández-Cuadros Marcos Edgar, Pérez-Moro Olga Susana, Albaladejo-Florin María Jesús, Alava-Rabasa Sandra. El ozono intraarticular modula la inflamación, mejora el dolor, la rigidez, la función y tiene un efecto anabólico sobre la artrosis de rodilla: estudio cuasi-experimental prospectivo tipo antes-después, 115 pacientes. Intra-articular Ozone modulates inflammation, ameliorates pain and rigidity, improves function and has anabolic effect on knee osteoarthritis: a prospective quasiexperimental before-andafter study, 115 patients. Rev Soc Esp Dolor 2020. doi: https:// doi.org/10.20986/resed.2020.3775/2019.

17. Shi Y, Wang Y, Shao C, Huang J, Gan J, Huang X, et al. COVID-19 infection: the perspectives on immune responses. Cell Death Differ. 2020;27:1451-4. https://doi.org/10.1038/ s41418-020-0530-3.
18. Qin C, Zhou L, Hu Z, Zhang S, Yang S, Tao Y., Tian DS Dysregulation of immune response in patients with COVID-19 in Wuhan, China. 2020 China (February 17, 2020).

19. Huang, C., Wang, Y., Li, X., Ren, L., Zhao, J., Hu, Y., . \& Cheng, Z. (2020). Clinical features of patients infected with 2019 novel coronavirus in Wuhan, China. Lancet, 395(10223), 497-506.

20. Karakike E, Giamarellos-Bourboulis EJ. Macrophage activationlike syndrome: a distinct entity leading to early death in sepsis. Front Immunol. 2019;10.

21. Ruan Q, Yang K, Wang W, Jiang L, Song J. Clinical predictors of mortality due to COVID-19 based on an analysis of data of 150 patients from Wuhan, China. Intens Care Med. 2020:1-3.

22. Zhou, F., Yu, T., Du, R., Fan, G., Liu, Y., Liu, Z., . \& Guan, L. (2020). Clinical course and risk factors for mortality of adult inpatients with COVID-19 in Wuhan, China: a retrospective cohort study. Lancet, 395, 1054-1062.

23. Shimabukuro-Vornhagen A, Gödel P, Subklewe M, Stemmler HJ, Schlößer HA, Schlaak M, et al. Cytokine release syndrome. J Immunother Cancer. 2018;6(1):56. https://doi.org/10.1186/ s40425-018-0343-9.

24. Mehta P, et al. COVID-19: consider cytokine storm syndromes and immunosuppression. Lancet. 2020. https://doi.org/10.1016/S01406736(20)30630-9.

25. Siddiqi HK, Mehra MR. COVID-19 illness in native and immunosuppressed states: a clinical- therapeutic staging proposal. J Heart Lung Transplant. 2020;39:405-7.

26. Bocci V. Ozone: a new medical drug. 2nd ed. Dordrecht: Springer Verlag; 2011.

27. Iliakis E, Valadakis V, Vynios DH, Tsiganos CP, Agapitos E. Rationalization of the activity of medical ozone on intervertebral disc a histological and biochemical study. Riv Neuroradiol. 2001;14(1 suppl):23-30.

28. Paoloni M, Di Sante L, Cacchio A, Apuzzo D, Marotta S, et al. Intramuscular oxygen-ozone therapy in the treatment of acute back pain with lumbar disc herniation: a multicenter, randomized, double-blind, clinical trial of active and simulated lumbar paravertebral injection. Spine. 2009;4(13):1337-44.

29. Seyman D, Ozen NS, Inan D, Ongut G, Ogunc D. Pseudomona aeruginosa septic arthritis of knee after intra-articular ozone injection. New Microbiol. 2012;35(3):345-8.

30. Mawsouf N, El-Sawalhi MM, Shaheen AA, Darwish HA, Martinez-Sanchez, et al. Effect of ozone therapy on redox status in experimentally induced arthritis. Rev Esp Ozonoterapia. 2011;1(1):32-43.

31. Madrigal C. Tratado de Ozonoterapia. Madrid: Editorial la Salud Naturalmente; 2007.

32. Bocci VA. Scientific and medical aspects of ozone therapy. State of the art. Arch Med Res. 2006;37(4):425-35.

33. Babior BM, Takeuchi C, Ruedi J, Gutierrez A, Wentworth P. Investigating antibody-catalyzed ozone generation by human neutrophils. Proc Natl Acad Sci. 2003;100(6):3031-4.

34. Rowen RJ, Robins H. A plausible "penny" costing effective treatment for corona virus ozone therapy. J Infect Dis Epidemiol. 2020;6:113

35. Eren E, Saribek F, Kayalayci, Yilmaz N. How to cripple SARSCOV-2 virus with Ozone treatment thiol groups in viruses and SARS-COV-2, Traditional and Complementary Medicine, 2020.

36. Schoeman D, Fielding BC. Coronavirus envelope protein: current knowledge. Virol J. 2019;16:69.

37. Madu IG, Belouzard S, Whittaker GR. SARS-coronavirus spike S2 domain flanked by cysteine residues C822 and C833 is important for activation of membrane fusion. Virology. 2009;393:265-71.

38. Sharma VK, Graham NJ. Oxidation of amino acids, peptides and proteins by ozone: a review. Ozone Sci Eng. 2010;32(2):81-90.

39. Reth M. Hydrogen peroxide as second messenger in lymphocyteactivation. Nat Immunol. 2002;3:1129-34. 
40. Martinez-Sanchez G. Mechanisms of action of O3. Genomic pathways. Ozone Ther Glob J. 2019;9(1):21-2.

41. Delgado-Roche L, Riera-Romo M, Mesta F, Hernández-Matos Y, Barrios JM, Martínez-Sánchez G. Medical ozone promotes Nrf2 phosphorylation reducing oxidative stress and proinflammatory cytokines in multiple sclerosis patients. Rev Esp Ozonoterapia. 2018;8(2 Supp 1):48-9.

42. Martinez-Sanchez G, Delgado-Roche L. Up-date on the mechanisms of action of ozone through the modification of cellular signaling pathways. Role of Nrf2 and NFkb. Rev Esp Ozonoterapia. 2017;7(2):17-8.

43. Bocci V, Valacchi G. Nrf2 activation as target to implement therapeutic treatments. Front Chem. 2015;3:4.

44. Re L, Martinez-Sanchez G, Bordicchia M, et al. Is ozone preconditioning effect linked to Nrf2/EpRE activation pathway in vivo? A preliminary result. Eur J Pharmacol. Nov 5 2014;742: 158-62.
45. Fernandez-Cuadros ME, Perez-Moro OS, Mirón-Canelo JA. Could ozone be used as a feasible future treatment in osteoarthritis of the knee. Divers Equal Health Care. 2016;13(3):232-9.

46. Fernández-Cuadros ME, Pérez-Moro OS, Albaladejo-Florín MJ, Álava-Rabasa S, Tobar-Izquierdo M, Rodriguez-de-Cía J. Sci Rep. 2020;2(1) [In press].

47. Schwartz A, Martinez-Sánchez G. Uso potencial complementario y compasivo de la ozonoterapia sistemica en el COVI-19. AEPROMO, 2020, In Press.

48. Rowen RJ. Ozone and oxidation therapies as a solution to the emerging crisis in infectious disease management: a review of current knowledge and experience. Med Gas Res. 2019;9(4):232.

49. Schwartz A, Sanchez GM, Sabah F Declaración de Madrid sobre la ozonoterapia. 2 a edição. 2015

Publisher's Note Springer Nature remains neutral with regard to jurisdictional claims in published maps and institutional affiliations. 